\title{
REPRESENTASI CITRA PEREMPUAN IDEAL DALAM KARAKTER
}

\author{
BLACK WIDOW \\ Daniar Wikan Setyanto ${ }^{1}$, Toto Haryadi ${ }^{2}$ \\ 1,2Desain Komunikasi Visual, Fakultas Ilmu Komputer, \\ Universitas Dian Nuswantoro, Jalan Imam Bonjol 207 Semarang \\ daniarwikan@dsn.dinus.ac.id, toto.haryadi@dsn.dinus.ac.id
}

\begin{abstract}
Abstrak: Black Widow merupakan salah satu karakter heroine yang telah menjadi imajinasi penonton di seluruh dunia dalam hal gambar diri khususnya dalam hal kiblat kecantikan dan seksualitas ideal para wanita di seluruh dunia. Citra yang ada pada karakter Black Widow merupakan gejala kapitalisme yang merupakan bentuk kontruksi citra atau representasi perempuan lewat media film. Representasi yang muncul pada karakter Black Widow merupakan pencapaian identitas perempuan yang melampaui tubuh fisik karena juga berkaitan dengan kualitas-kualitas tertentu yang harus dicapai oleh perempuan. Penelitian ini dilakukan untuk memahami secara kritis topik di atas berdasarkan analisa mendalam menggunakan pendekatan induktif dan metode deskriptif kualititatif. Sehingga mampu menganalisis media secara komprehensif dan hasil dari penelitian ini yaitu dapat melihat proses pembentukan makna khususnya yang berkaitan dengan citra perempuan ideal yang ada pada karakter Black Widow dari sudut pandang feminisme. Penelitian ini juga bisa menjadi acuan untuk penelitian kajian karakter heroine selanjutnya, tidak hanya untuk karakter film barat, namun juga memungkinkan untuk heroine lokal asli Indonesia. Urgensi dari penelitian ini adalah untuk menemukan gagasan baru tentang perempuan ideal yang muncul dari perpektif media khususnya karakter heroine yang diwakili oleh karakter Black Widow.
\end{abstract}

Kata Kunci : Black Widow, feminisme, heroine, representasi, kecantikan ideal, Marvel

Abstract: Black Widow is one of the heroin characters who has succeeded in embracing public's imagination about self-image, especially in term of the ideal beauty and sexuality orientation for women around the world. The image belong to Black Widow character is a capitalism symptom as construction or representation of women's image through film media. The representation that appears on Black Widow is the achievement of women's identity which become over physical image because it relates to any quality of thing which must be achieved by women. This research was conducted to understand topic above critically based on in-deep analysis through inductive approach and descriptive-qualitative method. So by doing this research, author was able to analyze the media comprehensively and the result of this research is able to understand the process of meaning construction especially has related to the women's ideal image in Black Widow character from feminism view. This research is also potential to be a reference of further studies of heroine, not only for western film character, but also for Indonesian local ones. The urgency of this 
research is to find new ideas about the ideal woman that emerges from the media perspective, especially the heroine character represented by the Black Widow character. Keywords : Black Widow, feminism, heroine, representation, ideal beauty, Marvel

\section{PENDAHULUAN}

Kemajuan ilmu pengetahuan, teknologi dan seni saat ini menjadi motor penggerak perkembangan dunia perfilman global salah satunya fenomena film bergenre pahlawan super yang banyak menampilkan efek special computer yang makin Nampak realistis. Marvel Cinematic Universe (MCU) melalui karakterkarakter pahlawan super menjadi komoditas bisnis yang menggiurkan di dunia perfilman dunia. Hal tersebut yang dibuktikan dengan data terakhir yang penulis peroleh pada bulan Januari 2020, yang dikutip dari www.boxofficemojo.com ${ }^{1}$, film pamungkas dari MCU phase ketiga yaitu Avengers Endgame menjadi film dengan pendapatan terbesar diseluruh dunia sepanjang masa dengan pencapaian sebesar \$2.797.800.564 dan mengalahkan film Titanic yang sebelumnya menduduki posisi tersebut. Hal ini bukan hanya menunjukkan bahwa hiburan bertema pahlawan super menjadi komoditas yang sangat menguntungkan di dunia film bagi para sineas Hollywood namun memiliki banyak penggemar di seluruh dunia.

Di sisi lain, fenomena film pahlawan super pada kenyataannya bukan hanya menjadi prioritas persoalan mencari keuntungan saja, tetapi juga menjadi ikon populer yang mampu menjadi pembicaraan mengenai budaya populer di dunia termasuk masalah sosial politik, gender dan isu tentang perempuan. Hal ini didukung oleh penelitian Sulistiyawati dan Ulumuddin (2019:174) bahwa aktor/karakter dan kostum/busana merupakan bagian komponen visual film selain Teknik pengambilan gambar, properti, lokasi, dan pemandangan, yang berfungsi mengkomunikasikan suasana hati, emosi, serta yang utama menyampaikan gagasan tertentu termasuk persoalan gender (Sulistiyawati, 2019). Setiap karakter pahlawan super memiliki sifatnya masing-masing dan menjadi

\footnotetext{
${ }^{1}$ https://www.boxofficemojo.com/title/tt4154796/?ref_=bo_cso_ac
} 
sumber inspirasi yang berpotensi untuk ditiru oleh masyarakat atau audiens yang menontonnya, karena dalam penggambaran karakter pahlawan super terdapat banyak ideologi dan nilai-nilai yang positif yang bisa diambil. Di antara karakter pahlawan super tersebut terdapat juga karakter pahlawan super berjenis kelamin perempuan atau yang disebut heroine, salah satu heroine yang populer adalah Natasha Romanoff yang lebih familiar dengan nama Black Widow. Seperti halnya karakter pahlawan super pria maka karakter heroine pun juga menjadi ikon populer, karena karakter heroine tersebut bakal menjadi inspirasi publik dalam hal citra diri khususnya mengenai citra perempuan ideal. Citra kecantikan seorang heroine tersebut akan menjadi inspirasi bagi masyarakat bukan hanya di satu lokasi saja namun di seluruh dunia. Hal tersebut sebagai implikasi kesuksesan filmfilm Marvel Cinematic Universe (MCU) yang mencakup seluruh dunia.

Dalam sudut pandang kajian budaya, setiap penggambaran visual yang ada pada karakter Black Widow mampu memproduksi berbagai makna termasuk mengenai persoalan identitas perempuan yang sering kita sebut dengan istilah representasi, misalnya dalam penampilan digambarkan sebagai seorang wanita muda yang memiliki tubuh sexy, atletis, wajah yang cantik, pakaian yang modis, pintar, baik hati, serta perilaku yang menarik lainnya. Black Widow membungkus tubuhnya dengan kostum yang menonjolkan daya tarik seksual yang meskipun tertutup nampak ketat sehingga menonjolkan bentuk tubuhnya yang ideal. Hal ini mengarahkan pada kontruksi daya tarik fisik yang melekat pada representasi karakter Black Widow. Meskipun hanya karakter fiktif, Black Widow lekat dengan simbol-simbol feminisme, bisa dikatakan bahwa karakter Black Widow adalah sebuah citra penampilan dan kecantikan ideal perempuan yang melampaui standar lokalitas dan menjadi standar kecantikan perempuan yang mengglobal.

Feminisme kini menjadi salah satu isu penting yang dihadirkan dalam filmfilm Hollywood bertema superhero karena saat ini banyak ditemukan karakterkarakter perempuan di dalamnya. Pemikiran tentang feminisme bukan hanya 
tentang kesetaraan hak-hak perempuan di masyarakat global namun juga menyinggung isu-isu seksualitas. Sebagai contoh karakter heroine Black Widow yang merupakan salah satu ikon populer yang dimiliki oleh Marvel yang secara gamblang dalam merepresentasikan pemikiran dan wacana tentang feminisme. Penampilan para heroine dalam film-film superhero merupakan simbol yang mewakili perjuangan perempuan untuk mengaktualkan dominasi gendernya dalam masyarakat yang saat ini cenderung patriarki. Sebagai seorang heroine karakter Black Widow memiliki potensi bagi peneliti untuk dijadikan contoh yang mewakili simbol gerakan feminisme dalam di dunia perfilman yang menuntut kesetaraan gender, sekaligus melawan belenggu yang sarat dengan dominasi pria serta menjadi bentuk kontra propaganda patriarki.

Berbagai macam pemaknaan terhadap karakter Black Widow dalam penelitian ini akan membuktikan bahwa karakter tersebut merupakan sebuah pencapaian representasi identitas yang melebihi citra fisik dari perempuan, karena dalam diri Black Widow juga memiliki banyak representasi yang bersifat implisit mengenai kriteria-kriteria bersifat non fisik. Representasi yang bersifat fisik bisa diamati dari apa yang tampak dari karakter heroine, sebagaimana dijelaskan Setyanto \& Adibawa bahwa secara visual dalam karakter superhero melekat atribut yang merepresentasikan kelebihan-kelebihannya melalui ciri-ciri khusus meliputi: tampilan fisik, kelebihan dan kekuatan super, kostum, aksesoris, serta warna yang melekat pada kostum dan aksesorisnya (Setyanto \& Adiwibawa, 2018).

Penelitian hanya fokus pada salah satu karakter penting dari rangkaian film Marvel Cinematic Universe (MCU) yaitu Black Widow (Natasha Romanoff) dan mengambil beberapa beberapa sample dari film-film MCU yang manghadirkan karakter ini seperti Iron man 2 (2010), The Avengers (2012), Iron Man, 3 (2013), dan Avengers : Age of Ultron (2015), sedangkan untuk film Captain America : Winter Soldier (2015), Captain America : Civil War (2016), Avengers : Infinity War 
(2018), Captain Marvel (2019), Avengers Endgame (2019) dan Black Widow (2020) hanya diwakilkan untuk sampling dari penampilan Black Widow tanpa mengkaji scene film karena adegan kemunculan Black Widow dalam film tersebut relatif mirip dengan film-film sebelumnya.

Asumsi dasar yang menjadi latar belakang penelitian ini adalah bahwa Karakter Black Widow merupakan representasi penggambaran sosok ideal perempuan yang mendunia/mengglobal yaitu sebuah produksi citra yang melebihi wilayah lokalitas tertentu dan berhasil menjadi tren global. Selain itu juga representasi kecantikan ideal dalam karakter Black Widow melampaui citra tubuh fisik dari perempuan, karena dalam karakter tersebut ada banyak kualitas-kualitas yang dicapai selain cantik yang bersifat fisik. Sedangkan tujuan dari penelitian ini adalah mendapatkan konsep-konsep serta kriteria-kriteria mengenai citra "kecantikan ideal" yang ada dalam karakter heroine Black Widow.

Saat ini feminisme merupakan kajian penting bagi kaum perempuan yang banyak dikumandangkan melalui media massa salah satunya film. Film menjadi saluran yang menyampaikan pesan-pesan feminisme sebagai wacana dalam masyarakat, sehingga kemungkinan besar membawa perubahan pada masyarakat atau setidaknya dipengaruhi oleh kondisi sosial yang berlaku di dalam masyarakat tersebut. Pesan-pesan feminisme dalam film berhubungan dengan peran dari karakter-karakter perempuan yang muncul dalam film tersebut. Keadaan ini menjadikan karakter-karakter perempuan dalam film bisa digambarkan dalam banyak peran dan fungsi tertentu yang menunjukkan bahwa perempuan bisa sejajar dengan laki-laki bahkan melebihinya atau menjadi dominan. Seiring berjalannya waktu feminisme juga membelajari mengenai bagaimana seharusnya perempuan bertindak dan berperilaku di tengah-tengah masyarakat (Rachmah Ida, 2014). Dalam kajian ilmiah, feminisme sendiri dipahami sebagai gerakan yang ditujukan untuk menentukan, membangun, dan mempertahankan hak-hak politik, ekonomi, dan sosial yang sama bagi perempuan. Feminisme mendukung 
kesetaraan gender dan menganggap bahwa manusia dan lingkungan itu samasama penting (Sulastri, 2011). Dalam konteks penelitian media, feminisme seringkali menjadi salah satu ideologi penting terkait dengan representasi identitas perempuan yang muncul di media massa. Dengan demikian penelitian ini diharapkan akan memperkaya referensi mengenai konsep-konsep representasi perempuan yang ditampilkan oleh media dimana setiap representasi tersebut merupakan temuan-temuan baru yang akan menjadi kajian penting dalam penelitian mengenai perilaku perempuan secara khusus perilaku perempuan yang dipengaruhi oleh media film. Dengan demikian manfaat penelitian ini adalah untuk menemukan gagasan baru tentang perempuan ideal yang muncul dari perpektif media khususnya karakter heroine yang diwakili oleh karakter Black Widow.

Sebagai literature review, terdapat penelitian yang memiliki arah sama dengan penelitian ini, yakni mengkaji fenomena feminisme dalam karakter superhero. Sebagaimana telah dilakukan oleh Fauzi yang mengkaji kesetaraan gender dalam film Captain Marvel, sebagai karakter heroine milik MCU selain Black Widow (Fauzi, 2019). Hasil kajian penelitian tersebut juga memiliki arah yang sama dengan hasil penelitian ini yakni peran wanita yang mengeksplorasi kekuatan dan kecerdasan untuk menjalankan sebuah misi. Penelitian kedua yang juga memiliki persamaan tema feminisme yaitu sebagaimana yang telah dilakukan oleh Sutanto yang mengulas feminisme dalam film "Spy", film mata-mata agen rahasia yang melakukan penyamaran agar bisa menyusup. Kajian film "Spy" juga mengangkat potensi kaum perempuan dalam kepemimpinan, berpikir kritis, berani mengambil risiko, dan sebagainya (Sutanto, 2017). Artinya, penelitian representasi citra perempuan ideal dalam karakter Black Widow ini bersifat saling mendukung dan saling melengkapi dengan penelitian lain yang bertema sama, meskipun memiliki kajian karakter atau film yang berbeda. 


\section{METODE PENELITIAN}

Kajian ini meneliti representasi identitas dalam karakter Black Widow dalam film maka dari itu diperlukan kajian yang bersifat deskriptif kualitatif. Metode deskriptif kualitatif biasanya bersifat analisis yang bersifat subyektif dari peneliti. Namun demikian, analisis tersebut bersifat mendalam karena dilakukan melalui observasi langsung terhadap obyek yang diteliti, sedangkan deskripsi akan dilakukan dengan cara mengulas obyek visual tersebut serta mendeskripsikannya secara mendalam menggunakan bahasa verbal, yang dilanjutkan dengan deskripsi visual tahap berikutnya dengan cara menganalisis atau mengulas makna-makna yang ada pada obyek visual tersebut dengan menginterpertasikan sesuai dengan representasi visual (scene, adegan, dialog, gambar) yang ada pada obyek penelitian yaitu karakter Black Widow. Penelitian ini mengulas representasi dari setiap pengadeganan maka yang digunakan adalah pendekatan semiotika dari John Fiske. Teori semiotia dari John Fiske sangat erat dengan kajian budaya terkait representasi karena menurut Jogn Fiske setiap pemaknaan representasi dikomunikasikan lewat gambar, suara, kata-kata yang muncul dari layar sebagai media (Chornelia, 2013). Berikut adalah bagan metode analisis yang digunakan untuk membedah representasi dari karakter heroine.

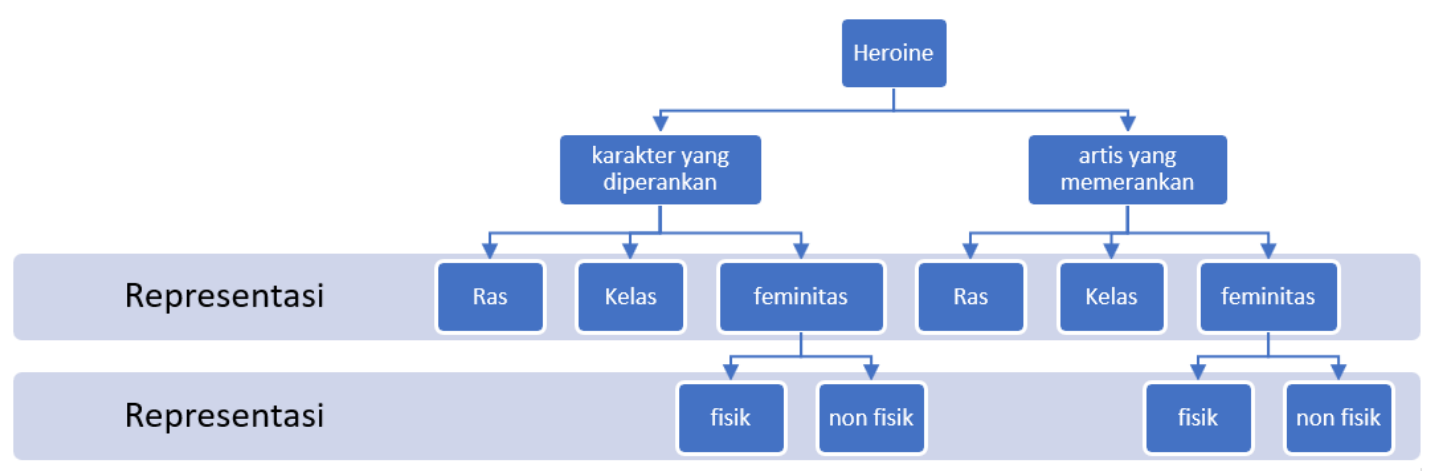

Gambar 1. Bagan Metode Analisis 


\section{HASIL DAN PEMBAHASAN}

Aktifitas menonton film adalah aktifitas yang problematis, pada saat menonton film sebenarnya secara tidak langsung penonton melihat layar yang di dalamnya ada beragam representasi. Ragam representasi itu adalah dari orangorang yang terlihat pada layar, di setiap tokoh yang muncul pada film menampilkan representasi karakter yang mereka perankan sekaligus representasi dari diri mereka sendiri. Layar kini telah menggantikan fungsi cermin karena pada saat melakukan aktivitas bercermin maka yang terlihat adalah representasi dirisendiri, serta citra diri sesuai dengan yang diinginkan (Prabasmoro, 2003). Setiap aktifitas bercermin menimbulkan ekspektasi tentang apa yang mau dilihat dalam cermin. Secara alamiah ketika bercermin, kita menginginkan citra atau representasi semenarik mungkin.

\section{Gambar Dan Profil Black Widow Yang diperankan Oleh Scarlett Johansson}

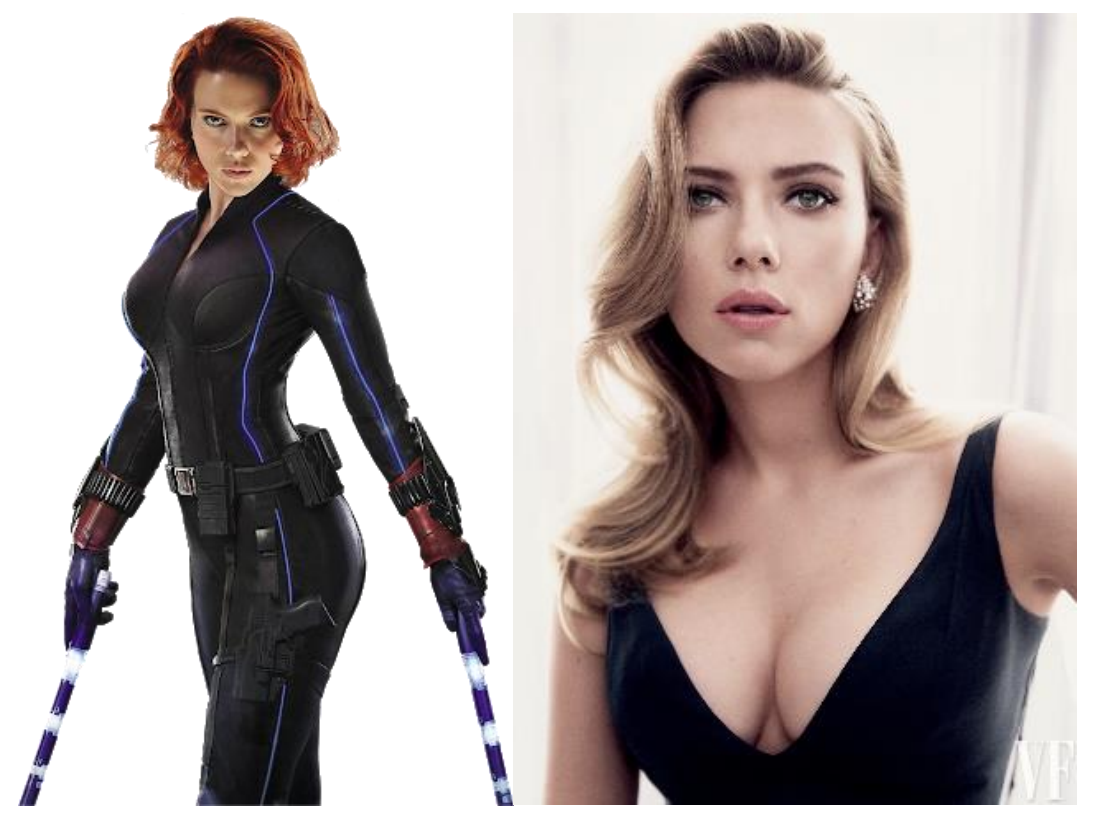

Gambar 2. Foto penampilan karakter Black Widow dan artis Scarlett Johansson Sumber: marvel.com dan imdb.com 
Tabel 1. Foto Profil Black Widow (heroine) dan Scarlett Johanson (pemeran)

\begin{tabular}{|c|c|}
\hline Karakter superheroine & Artis yang memerankan \\
\hline Black Widow/Natasha Romanoff & Scarlett Johansson \\
\hline Penerbit : Marvel Comics & Profil : \\
\hline Debut : Tales of Suspense \#52 (1964) & Lahir: 22 November 1984, \\
\hline Kreator : Stan Lee & Manhattan, Kota New York, New \\
\hline Asal : Bumi & York, Amerika \\
\hline Tim dan Mitra : SHIELD, AVENGERS, Captain & Tinggi : $167 \mathrm{~cm}$ \\
\hline America, Nick Fury, Hawkeye, Bruce Banner & Pasangan: Romain Dauriac (2014- \\
\hline Love Interest : Bruce Banner & 2017), Ryan Reynolds (2008-2011) \\
\hline Kemampuan : Kecerdasan diatas rata-rata, & Anak: Rose Dorothy Dauriac \\
\hline ahli menyamar, kemampuan bela diri & Ras : kulit putih \\
\hline
\end{tabular}

Berikut adalah deskripsi tentang karakter Black Widow: dalam rangkaian film MCU Black Widow/ Natasha Romanoff pertama kali muncul di film Ironman 2 (2010) sebagai salah satu mata-mata paling mematikan di dunia anggota dari SHIELD. Natasha ke Amerika dengan tugas menyusup ke Stark Industries sebagai salah satu pegawai Stark. Namun setelah identitasnya terbongkar Natasha akhirnya menjadi ikut membantu Stark dalam menghadapi Hydra dan musuhmusuh lainnya bersama dengan tim Avengers. Dalam film maupun komik, Black Widow digambarkan memiliki banyak kekuatan seperti merancang strategi, ahli bela diri dan agen rahasia super, awet muda, kekebalan tubuh serta stamina yang lebih dari manusia biasa, keahlian menyamar, ahli senjata dan menembak. Selain itu Black Widow juga seringkali memanfaatkan kecantikan dan pesona tubuhnya untuk memperdaya musuh.

Natasha juga bermitra dengan Steve Rogers (Captain America) dan Tony stark (Iron Man). Dalam film Avengers Age Of Ultron, Natasha diceritakan sempat 
menjalin hubungan dengan Bruce Banner (Hulk). Dalam film tidak pernah diceritakan detail mengenail asal-usul Natasha mendapatkan kemampuannya namun dalam komiknya diceritakan Natasha mendapatkan serum super soldier yang sama seperti milik Steve rogers (Captain America). Serum tersebut membuatnya mempunyai kemampuan fisik melebihi manusia biasa. Kostum Natasha dalam film sering berubah namun secara keseluruhan memiliki warna hitam, ketat (menyesuaikan bentuk tubuh), kuat, tahan suhu tinggi dan peluru kaliber kecil. Black Widow sering membawa berbagai peralatan mata-mata canggih, seperti sebuat tali yang digunakannya berloncatan dari gedung ke gedung yang dinamakan "widow line". Senjata utama Natasha adalah "widow bite", Gauntlet yang mampu memancarkan sengatan listrik.

Berikut adalah deskripsi tentang pemeran Black Widow: Scarlett Johansson adalah aktris dari Amerika Serikat yang merupakan salah satu aktris dengan bayaran tertinggi di dunia dari 2014 sampai 2016. Scarlett Johansson juga termasuk dalam Forbes Celebrity top 100 dan Hollywood Walk of Fame. Scarlett Johansson Lahir dan dibesarkan di Manhattan, New York, dan memulai debutnya dalam film komedi North (1994) dan dinominasikan untuk penghargaan Independent Spirit atas perannya dalam film Manny \& Lo (1996). Pengakuan juga diperolehnya atas karya dalam The Horse Whisperer (1998) dan Ghost World (2001). Penampilan bagusnya dalam film Lost in Translation Johansson tahun 2003, menjadikannya sebagai Aktris Utama Terbaik dalam penghargaan BAFTA. Karir lain selain di industri film yaitu industri musik, dengan rilisnya dua album berjudul: Anywhere I Lay My Head (2008) dan Break Up (2009). Karir sebagai Black Widow dalam Marvel Cinematic Universe dilakoni mulai tahun 2008. Lewat karakter Black Widow terkait dengan kecantikan ideal digambarkan dengan stereotip ras kulit putih dengan kelas menengah atas, hal tersebut terlihat dari representasi yang dimunculkan dari artis yang memerankan tokoh Black Widow yaitu Scarlett Johansson. 


\section{Representasi Kecantikan Pada Karakter Black Widow}

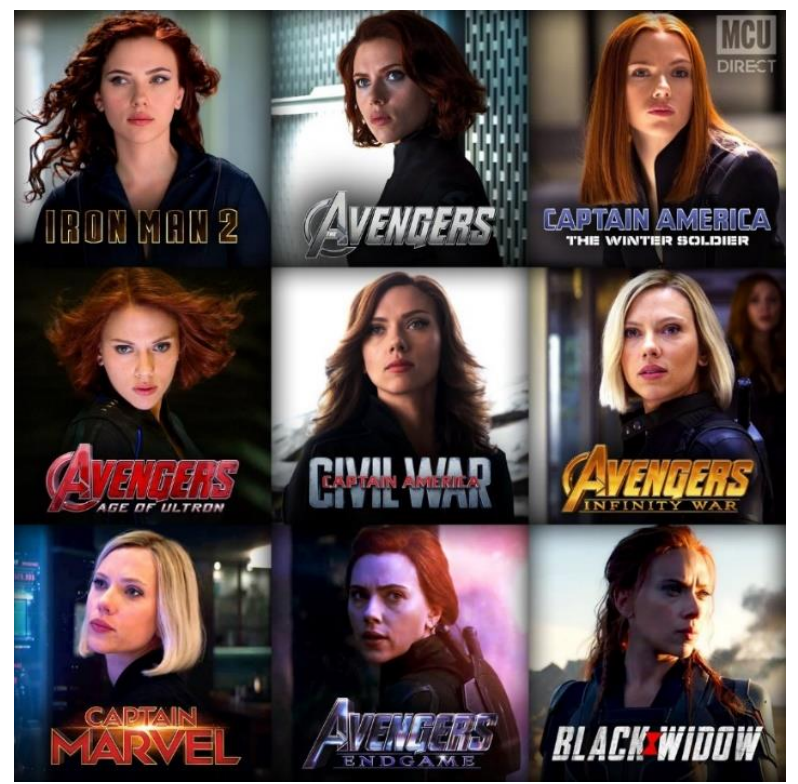

Gambar 3. Foto penampilan karakter Black Widow di beberapa film MCU Sumber: reddit.com

Salah satu representasi kecantikan pada penampilan karakter Black Widow menjadi salah satu karakter yang paling menonjol adalah pada gaya tata rambut. Tata rambut dan warna rambut pada karakter Black Widow pada setiap penampilannya selalu berubah pada setiap kemunculannya mulai dari Ironman 2 (2010) sampai film Black Widow (2020) sebagaimana tampak dalam gambar 2 di atas. Rambut menjadi salah satu representasi kecantikan yang penting bagi perempuan karena diartikan sebagai "mahkota perempuan" dan menjadi penanda sifat feminim. Meskipun selalu berubah gaya, tampilan rambut dari Black Widow semuanya memiliki panjang yang melebihi dagu. Representasi "rambut Panjang" ini menjadi satu-satunya yang konsisten pada representasi gaya rambut Black Widow. Rambut panjang menurut Kurt Stenn dalam bukunya "'Hair : $a$ Human History" menjadi simbol akan sifat feminim dari perempuan, berlawanan 
dengan rambut pendek yang menjadi simbol maskulinitas. Rambut panjang juga menjadi simbol dari kehormatan dan status sosial dari perempuan (Stenn, 2016).

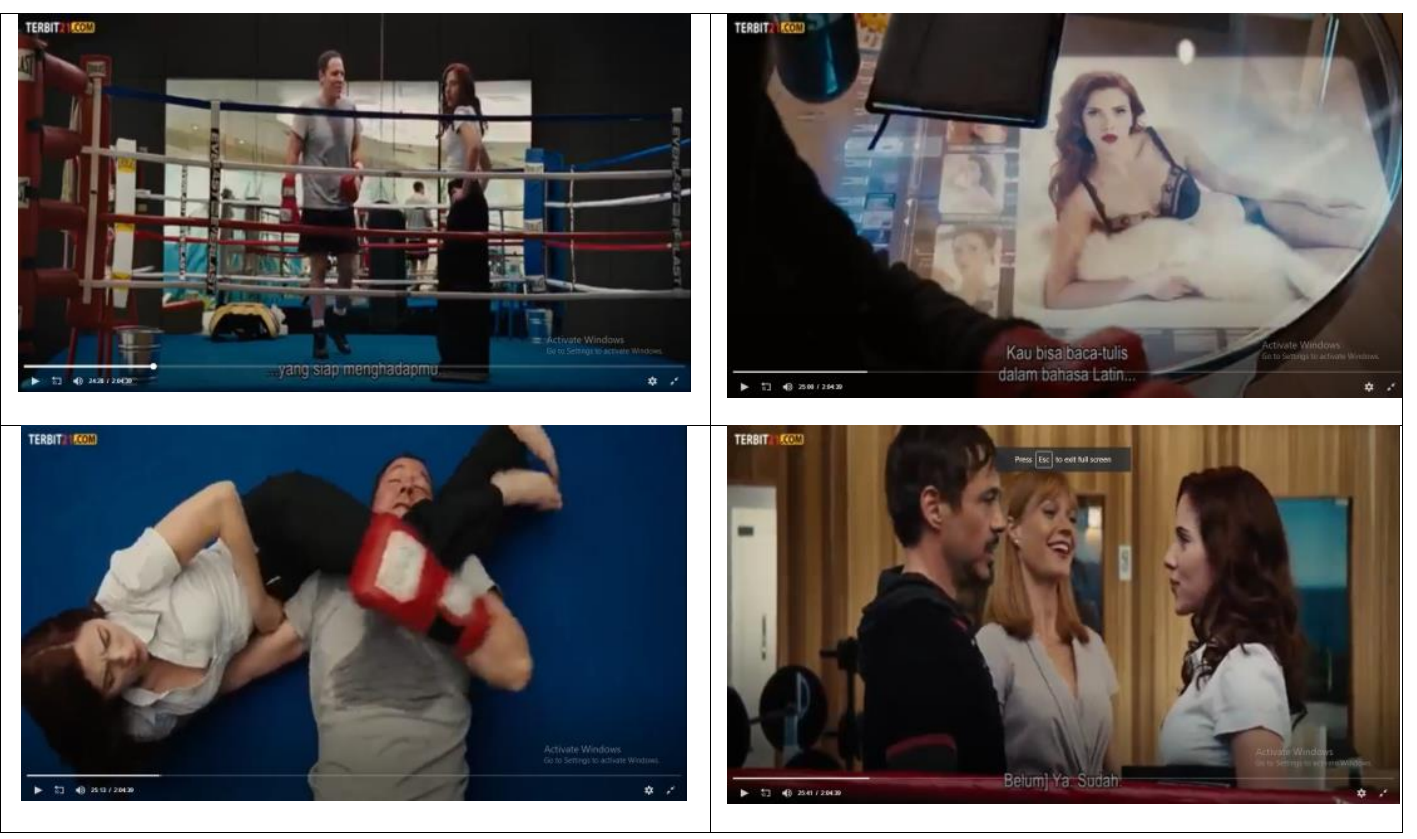

Gambar 4. Scene saat Tony Stark Melihat profil Natasha dan saat Natasha melawan Happy Sumber : Cuplikan Film Ironman (2010)

Gambar 4 adalah kemunculan perdana Black Widow pada film Ironman 2 (2010), diceritakan pada scene tersebut Black Widow/Natasha yang saat itu sedang diperkenalkan kepada Tony Stark oleh Pepper Pots sebagai salah satu karyawati Stark Industries. Tony Stark mencari profil Natasha di internet dan muncul banyak foto seksi Natasha. Selain foto seksi dalam pencarian profil Natasha oleh Tony Stark juga memunculkan berbagai macam representasi dari karakter tersebut seperti kemampuan dari Natasha menguasai banyak bahasa asing serta menguasai bela diri. Adegan perkenalan Natasha ini ditutup dengan adegan dikalahkannya karakter Happy (asisten dan sahabat Tony Stark) oleh Natasha dengan mudah dalam sebuah latihan.

Representasi yang ditunjukan pada adegan tersebut jelas menunjukkan adanya standar ganda pada perempuan. Setidaknya ada 3 kualifikasi yang 
ditunjukkan pada karakter Black Widow pada adegan tersebut, kualifikasi pertama adalah representasi kecantikan fisik yang ditunjukan pada foto-foto seksi dari karakter Natasha, kualifikasi kedua adalah representasi akan kemampuan otak atau kecerdasan yang ditampilkan pada saat Tony Stark melihat profil Natasha yang dipenuhi dengan prestasi akademik serta kemampuannya dalam menguasai banyak bahasa asing, sedangkan kualifikasi ke tiga adalah kemampuan fisik yang dalam scene tersebut diperlihatkan lewat adegan perkelahian tidak seimbang antara Natasha denga Happy yang diakhiri dengan kemenangan mutlak Natasha melawan Happy yang merupakan seorang pria dengan tubuh lebih besar.
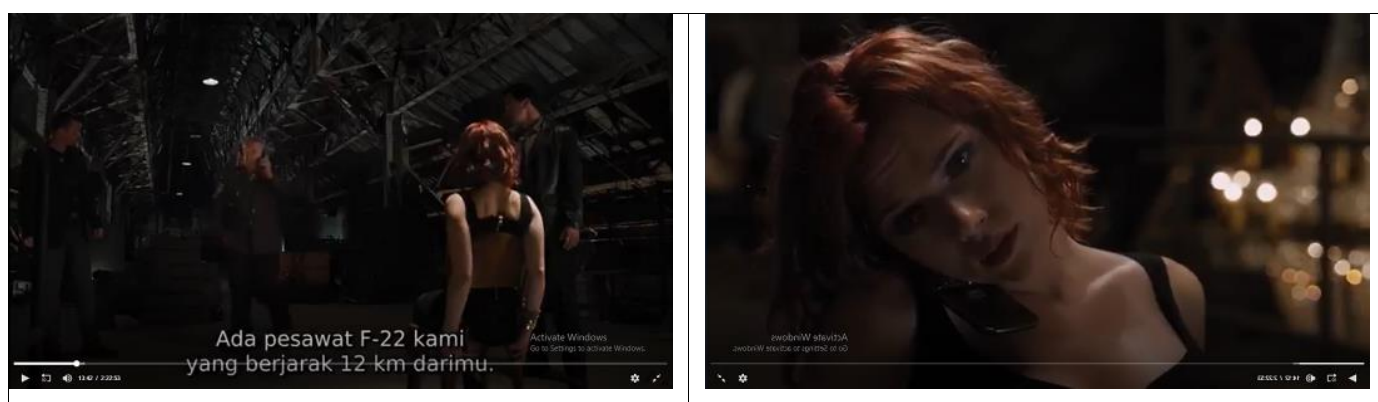

Gambar 5. Scene saat Natasha di Interogasi oleh Teroris Sumber : Cuplikan Film The Avengers (2012)

Adegan pada gambar 5 menceritakan pada saat Black Widow diinterogasi oleh beberapa pria di sebuah bangunan kosong. Tidak ada detail cerita mengenai adegan ini seperti siapa yang menginterogasinya dan bagaimana Black Widow bisa tertangkap. Yang penonton ketahui dari adegan ini adalah ada petunjuk bahwa pria yang menginterogasinya adalah sekelompok kriminal dari kelompok militer karena salah satu pria ditampilkan menggunakan seragam militer berpangkat tinggi. Black Widow dalam adegan ini sedang menyamar menjadi tawanan sehingga tampil hanya dengan pakaian minim dan memperlihatkan dia sedang dalam keadaan "seakan-akan" tidak berdaya. Dalam adegan selanjutkan Black Widow menerima telepon dari agen Coulson dari SHIELD, setelah itu Black Widow 
dengan mudah mengalahkan para pria yang menginterogasinya walau dengan tangan yang masih terikat kursi.
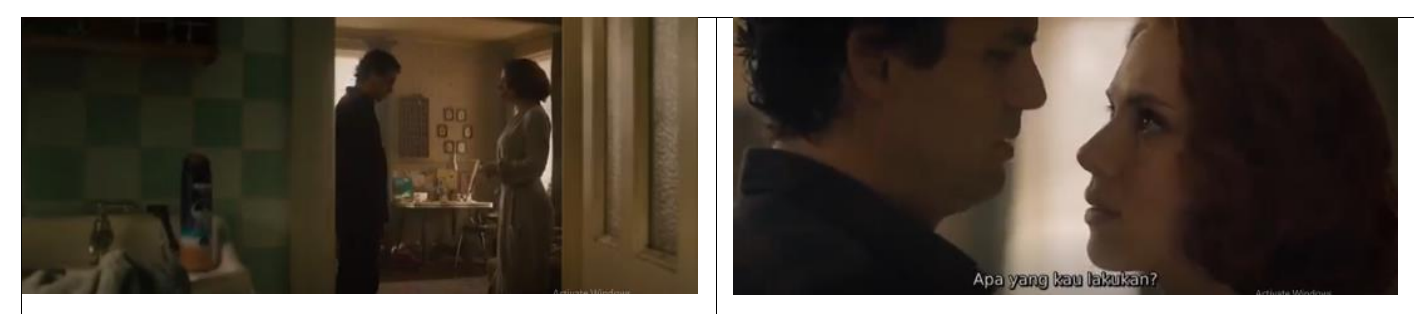

Gambar 6. Scene saat Natasha berbicara kepada Bruce Banner perihal hubungan mereka Sumber : Cuplikan Film The Avengers : Age Of Ultron (2015)

Gambar 6 merupakan scene perbincangan antara Bruce Banner dan Natasha pada saat berada di kediaman Hawkeye sesaat setelah pertempur dengan Ultron. Pada adegan tersebut Natasha menjelaskan kepada Banner bahwa dirinya telah "disterilkan", sebuah istilah yang digunakan untuk menjelaskan bahwa dirinya dalam keadaan mandul atau tidak bisa memiliki anak. Natasha juga merasa dirinya adalah monster sama seperti Hulk yang ada pada diri Banner sehingga Natasha merasa bahwa hubungan mereka tidak bisa dilanjutkan. Scene ini merupakan salah satu representasi feminisme yang ada pada karakter heroine dimana perempuan masih terikat pada konsep bahwa perempuan "seutuhnya" adalah perempuan yang menjadi ibu atau perempuan yang bisa memiliki anak, oleh karena itulah karakter Natasha merasa dirinya tidak layak bersanding dengan Banner karena merasa dirinya adalah monster.

Berdasarkan hasil analisis yang dimulai dari gambar 2 hingga gambar 5 di atas, bisa disimpulkan bahwa representasi citra perempuan ideal, dalam hal ini dari karakter Black Widow, direkonstruksi dari kombinasi berbagai fantasi dan kenyataan dalam kehidupan saat ini. Representasi merupakan upaya "menghadirkan kembali", dalam konteks penelitian ini yaitu menghadirkan kembali citra, karakter, dan persona ideal perempuan sesuai dengan fitrah yakni mempertahankan sifat asli/alamiah melalui fisik yang cantik (rambut, tubuh, 
busana) dan masih memiliki perasaan mencintai laki-laki (emosi-simpatik), namun di sisi lain perempuan juga harus memiliki kemampuan yang biasanya hanya ada dalam diri laki-laki yaitu cerdas (mengandalkan logika), kuat, pandai bela diri (adu fisik dan strategi), cekatan (berpikir cepat), berani mengambil risiko (perhitungan matang), dan sebagainya.

Representasi perempuan sebagaimana yang ditampilkan oleh karakter Black Widow sebenarnya mulai tampak dan sudah menggejala dalam kehidupan nyata sehari-hari, bahwa perempuan/wanita tidak bisa selalu mengandalkan kaum pria dalam berbagai situasi. Ada kalanya kaum wanita harus bisa menjaga diri dan menjalankan tugasnya, atau bahkan menggantikan peran kaum pria dalam pekerjaan tertentu. Inilah yang disebut sebagai standar ganda, bahwa di satu sisi representasi wanita dibentuk untuk menjadi kuat, cerdas, cekatan layaknya lakilaki, namun di sisi lain masih memiliki perasaan dan simpati layaknya kaum wanita pada umumnya. Dalam pengamatan yang dilakukan pada representasi perempuan pada karakter Black Widow maka bisa dilihat bahwa saat ini terjadi bias antara penggambaran sosok ideal pria dan wanita sehingga penelitian ini sependapat dengan penyataan Millet dalam (Adipoetra, 2016) mengenai perilaku laki-laki dan perempuan bukanlah berasal dari dalam "biologis" atau bersifat inheren, tetapi berasal atau diciptakan oleh budaya. Budayalah yang membentuk perilaku. Perbedaan temperamental unsur- unsur personalitas "feminine" dan “maskulin" diciptakan salah satunya oleh budaya sinema (Millet, 2000).

Dalam penelitian ini menunjukan bahwa Marvel Studios menggambarkan male gender role dan female gender role memiliki kemiripan sebagai seorang pahlawan super maka baik karakter pria dan perempuan digambarkan dapat mengendalikan orang lain, berani, suka mengambil resiko, rela berkorban demi orang lain, melindungi orang yang tidak bersalah, berjuang untuk keadilan dan menjadi panutan bagi orang lain. Selain itu, Marvel Studios berusaha untuk menggambarkan karakter pahlawan super sebagai seorang yang suka menolong 
dan membantu sesamanya, terbukti dengan usaha para karakter tersebut untuk menyelamatkan masyarakat atau dunia (Ridwan, 2014). Mereka mendahulukan kepentingan orang lain, dalam hal ini kepentingan masyarakat, sehingga mereka menjadi contoh/panutan yang baik bagi masyarakat. Marvel Studios juga menggambarkan sosok heroine sebagai pribadi yang tangguh, mandiri, dan berjuang untuk mencapai keinginan / cita-citanya.

\section{KESIMPULAN}

Meskipun Black Widow hanya tokoh fiktif dalam dunia komik maupun film Marvel, karakternya telah menjadi kemasan atau produk ekspresi nilai-nilai hasrat para feminis yang merepresentasikan perempuan dalam hal kekuatan serta seksisme. Dalam konteks identitas, karakter Black Widow adalah salah satu bukti bahwa dalam film, representasi perempuan seringkali masih berada dalam belitan standar ganda feminitas. Dalam pandangan Brooks bahwa stereotipe perempuan yang digunakan oleh film yang dimunculkan adalah perempuan kulit putih, berpakaian untuk laki-laki yang diidentifikasi sebagai heteroseksual, kompetitif, agresif, materialistik, individualistik, dan membalik peran terhadap laki-laki (Brooks; , 2011). Black Widow merupakan representasi dari perempuan yang telah bergerak maju menuju masyarakat androgin yaitu merupakan manusia yang seutuhnya merupakan campuran sifat-sifat positif feminin dan maskulin. Sosok Black Widow merupakan gabungan dari dua unsur feminim dan maskulin, pada satu sisi sosok yang tangguh, jago berkelahi, kuat dan tegas yang mewakili sifat maskulin, namun juga cantik secara fisik (seksual) serta simpatik yang mewakili sifat feminim. Representasi ini selalu ada setiap saat bersamaan dengan karakter Black Widow di setiap kemunculannya pada semua adegan yang ada pada filmfilm Marvel Cinematic Universe yang dipakai pada sampling penelitian ini.

Dapat disimpulkan bahwa representasi "citra perempuan ideal" dalam karakter Black Widow memunculkan problematika tersendiri bagi perempuan, 
karena bagi perempuan tidak banyak pilihan selain harus mengikuti kecenderungan stereotipikal yang dimunculkan lewat media. Problematika tersebut semakin besar ketika representasi perempuan dicitrakan oleh sebuah fantasi yang kelewat batas dan hanya ada di dunia hiper-realitas seperti halnya karakter heroine. Standar ganda tentunya menjadi sesuatu yang sangat sulit dicapai pada konteks realitas yang dihadapi oleh perempuan karena karakter Black Widow memiliki banyak sekali kriteria kualitas yang sangat superior yaitu cerdas, berpenampilan menarik, visioner, mandiri, independen, petualang dan aktif. Citra Black Widow adalah hasil dari kolaborasi citra ideal dari pria dan wanita, hasil dari fantasi penciptanya yang melompati realitas dan masuk ke wilayah hyper-realitas yang hampir mustahil dapat tercapai dan dimiliki oleh perempuan yang ada di dunia nyata ini.

Marvel sebagai pemegang hak cipta para karakter superhero masih memiliki banyak sekali karakter heroine seperti Captain Marvel, Scarlet Witch, Gamora, Agent Carter dan lain-lain. Kelemahan dari penelitian ini adalah minimnya pengambilan sample karena hanya terdiri dari satu karakter saja, untuk itu pada penelitian berikutnya diperlukan adanya studi mengenai representasi identitas karakter-karakter lainnya karena Marvel memiliki banyak sekali karakter heroine selain Black Widow. Bahkan penelitian serupa juga diperlukan untuk karakter heroine yang asli dari Indonesia seperti karakter Sri Asih, Valentine, Saras, dan lain-lain. Dengan keberagaman representasi dari banyak karakter heroine maka akan didapatkan juga lebih banyak data mengenai konsep-konsep perempuan ideal yang dikontruksi oleh media.

\section{PERNYATAAN PENGHARGAAN}

Penelitian ini merupakan penelitian kajian IPTEKS periode tahun 2019/2020 yang didanai oleh LPPM Universitas Dian Nuswantoro Semarang. 


\section{DAFTAR PUSTAKA}

Adipoetra, F. G. (2016). Representasi Patriarki dalam Film "Batas." Jurnal EKomunikasi Program Studi Ilmu Komunikasi Universitas Kristen Petra Surabaya, 4(1).

Brooks;, A. (2011). Posfeminisme and Cultural Studies (Sebuah Pengantar Paling Komprehensif). Retrieved from http://library.fis.uny.ac.id/opac/index.php?p=show_detail\&id=7838

Chornelia, Y. H. (2013). Representasi Feminisme Dalam Film "Snow White and the Huntsman." Jurnal E-Komunikasi, 1(3).

Fauzi, N. A. (2019). Captain Marvel : Kesetaraan Gender Dalam Perspektif Tokoh Superhero. Spectra, 3(2), 73-80.

Millet, K. (2000). Sexual Politics. 1970. Urbana: University of Illinois Press.

Prabasmoro, A. P. (2003). Becoming White, Representasi Ras, Kelas, Femininitas dan Globalitas dalam Iklan Sabun. Jogjakarta: Jalasutra.

Ida, R. (2014). Studi Media dan Kajian Budaya. Jakarta: Prenada Media Grup.

Ridwan. (2014). Male Gender Role Pada Karakter Superhero Dalam Film Produksi Marvel Studios. Jurnal E-Komunikasi, 2(3), 1-9. Retrieved from http://download.portalgaruda.org/article.php?article=358280\&val=6518\&ti tle=Male Gender Role Pada Karakter Superhero Dalam Film Produksi Marvel Studios

Setyanto, D. W., \& Adiwibawa, B. A. P. (2018). Membaca Warna Pada Karakter Superhero Marvel. Demandia, 03(02), 112-133.

Stenn, K. (2016). Hair: A human history. New York: Pegasus Books.

Sulastri. (2011). Benturan Budaya Berkomunikasi Dalam Perspektif Gender: Analisis Film Ayat-Ayat Cinta. Kafa'ah Journal of Gender Studies. https://doi.org/https://doi.org/10.15548/jk.v1i1 .41

Sulistiyawati, P. (2019). Analisis Komponen Visual Dasar Sinematografi Dalam Film Live Action "GREEN BOOK." Desain Komunikasi Visual, Manajemen Desain Dan Periklanan (Demandia), 4(2), 172-198.

Sutanto, O. (2017). Representasi Feminisme Dalam Film "Spy." Jurnal EKomunikasi, 5(1), 2-10. Retrieved from http://publication.petra.ac.id/index.php/ilmu-]komunikasi/article/view/616 4 